\title{
Local Excellence-Based Education that has Character in the Study of Biodiversity and its Conservation Efforts
}

\author{
Susanti Pudji Hastuti \\ Department of Biology Education \\ Universitas Kristen Satya Wacana \\ Salatiga, Central Java, Indonesia \\ susanti.hastuti@uksw.edu \\ Agna Sulis Krave \\ Magister of Biology \\ Universitas Kristen Satya Wacana \\ Salatiga, Central Java, Indonesia
}

\author{
Aldo Pramudya \\ Department of Biology Education \\ Universitas Kristen Satya Wacana \\ Salatiga, Central Java, Indonesia
}

Dan Elimelek Fuka

Magister of Biology

Universitas Kristen Satya Wacana

Salatiga, Central Java, Indonesia

\author{
Desy Fajar Priyayi \\ Department of Biology Education \\ Universitas Kristen Satya Wacana \\ Salatiga, Central Java, Indonesia
}

\begin{abstract}
Local Excellence Based Education (PBKL) is a policy of implementing education units by inviting teachers, instructors of integrated science and biology subjects to prepare material in accordance with the policy directions contained in the curriculum and the demands and needs of the community. The examples of PBKL-related applications are in Tanggungharjo, Grobogan, Central Java and Kuanfatu, SoE / Timor Tengah Selatan Regency (TTS), NTT province. The observations indicate that science teachers in the regions have not fully developed learning that leads to the utilization of the local potential of the region. The purpose of this study was to determine the local potential of terrestrial ecosystem in the Tanggungharjo area and SoE citrus diversity and to analyze its application based on the basic competencies of junior and senior high school science. Method of this research is a descriptive qualitative. The data collection technique is by observation, interview, open questionnaire and documentation. The subjects were science teachers, biology teachers, villagers, and school students. Conclusions of the local potential of terrestrial ecosystem that can be utilized are karst, paddy, soybean, and cornfield ecosystems, as well as $\mathrm{SoE}$ citrus diversity which can be used as local excellence based education (PBKL) characteristics of the region which is conservation efforts are implemented.
\end{abstract}

Keywords - Local Excellence Based Education (PBKL), Biodiversity, conservation

\section{INTRODUCTION}

Local potential is the potential of products or services both natural and artificial that are valuable and unique to a particular area and competitive power [1]. Local potential can be in the form of natural resource potential, culture, history and geography. Utilization of local potential as an application of contextual learning can teach students attitudes to explore knowledge from nature while still preserving the surrounding environment. Learning that utilizes local potential can affects the scientific attitude and character formation of students [2]. Learning biology especially as part of science which contain knowledge and positive attitudes towards local potential make the students have the motivation to learn and develop skills according to the local potential of their region [3].

Based on reference [4] relating to the management of education states the importance of organizing educational units based on local excellence, the teachers must prepare material in accordance with the policy direction set out in the curriculum and the demands and needs of the community through the contextual approach based on local excellence. Contextual approach is a learning approach that connects the material taught with the environment around students and their application in everyday life [5]. Through this concept, the learning process is expected to be more meaningful because it takes place scientifically in the form of student activities and students experience or observe the phenomena they learn. Contextual approach can be done by utilizing various sources and learning settings that are not always in the classroom. Reference [6] states that the surrounding environment can be an alternative source of student contextual learning. Utilization of the surrounding environment can be done by integrating the local potential of the region which is a manifestation of local excellence as a source of learning.

Through learning from the surrounding environment, students can connect the things that are found in everyday life with the concepts obtained in learning, besides that the characters care about the students environment can be formed. The teacher as the person in charge of learning needs to facilitate students to learn contextually by utilizing the local potential of their area. One alternative in learning by utilizing local local potential can reflect one of the Local Excellence Based Education (PBKL), as in [7] through learning experiences sourced from the potential for local excellence will train students ability to identify problems and solve problems associated with the potential for local excellence. Local excellence based education requires 


\section{METHOD}

relevance between the world of education and community needs, learning provided to students needs to be directed to connect the knowledge gained in schools with the reality in society.

The results of observations and interviews with science teachers (IPA) in the Tanggungharjo sub-district, Grobogan district shows that most of the biology learning process takes place with the lecture method, the teacher communicates concepts to students directly with the textbook learning source. The teacher has not yet fully developed learning that leads to the utilization of local potential. In general, Grobogan regency is an area that has relief of limestone mountains and hills and plains in the middle. Based on its geographical location and relief, Grobogan Regency is a district whose economy is sourced from the agricultural sector and is an area that tends to be difficult to get clean water [8]. Grobogan Regency has karst areas which are spread in Brati, Grobogan, Tawangharjo, Wirosari (North Kendeng Mountains) and Tanggungharjo and Kedungjati (South Kendeng Mountains) districts. In addition, the forest government area is 68,632,320 ha and community forest is 4,399 ha from the total area of Grobogan regency which is $197,586,420$ ha, indicating that the forest area is quite dominating the land use area in Grobogan region [9]. While the area of agricultural land also has broad coverage with rice as the second largest main commodity in Central Java [10]. Tanggungharjo sub-district is one of the sub-districts in the Grobogan region which has a dominant of terrestrial biome ecosystems in the form of karst areas, protected forests, and agricultural land areas. The area is very potential to be a source of student learning, especially in the field of science.

Nusa Tenggara Timur/NTT province has a unique plant namely "keprok SoE" orange. "Keprok SoE" are one of the leading commodities in Timor Tengah Selatan (TTS). "Keprok SoE" have been decreased plant populations due to disease which has resulted in decreased production. Orange rehabilitation is a starting point to increase production. Evaluation of increased production is done by analyzing the moving average of orange production data from 2005-2016. The results showed there was a tendency for an increase in production from 2013-2016, with an increase of 92.4\%.

Efforts to increase production were carried out by the relevant research institute, the Regional Government of the TTS Regency, the citrus farmers of the TTS Regency. Based on reference [11] found 129,351 "keprok SoE" trees died in 2001 to 2002. This death occurred because of the lack of adoption of good orange cultivation technology, in general the community of farmers planted oranges without maintenance (conservation). Conservation is a variety of efforts to preserve or protect natural resources that are threatened with extinction, or for certain purposes [12]. "Keprok SoE" orange is one of the local natural resources in TTS Regency, which needs to be preserved. One of the efforts to preserve these commodities is to introduce the conservation (maintenance) of "keprok SoE" through learning in schools [13].

\section{A. Data Collection Techniques and Instruments}

Data were collected through observation techniques, questionnaires, interviews, and documentation.

1) Observation

Observation technique is carried out before the research as a preliminary data and when the science learning process takes place. Observations were made with an observation sheet instrument.

\section{2) Open Questionnaire}

This questionnaire is a data collection technique through questions that are asked to someone or a group of people to get answers or responses and information needed by researchers. This list of questions is given during the initial observation to find out the Biology learning process that has taken place and the questionnaire at the end of each cycle to find out how the application of local potential as a source of learning science were carried out.

3) Interview

Interviews were conducted at the time of initial observation. Interviews were conducted based on interview guidelines that had been formulated previously. Interviewees are Science Teachers. Interviews were conducted to assess the strengths and weaknesses of the learning process that was carried out to be considered in the next cycle.

4) Documentation

Documentation was obtained from photographs and images related to this study.

\section{B. Data Analysis Techniques}

Analysis of the data by using descriptive qualitative techniques. Data in the form of words or sentences from observations are processed into meaningful sentences and analyzed qualitatively. For the validity of the data in this study also used triangulation techniques. Triangulation is a technique that combines various kinds of data collection techniques and existing data sources [14]. This research was carried out in stages according to the program of the Directorate General of Primary and Secondary Education Management (Dit. PSMA-DitjenMandikdasmen) in Fig. 1. The researcher conducted an inventory of potential local advantages, then determined the themes and types of local excellence. Furthermore the identified local advantages are mapped according to basic competencies and passed down in syllabus form. The research phase is based on this stage.

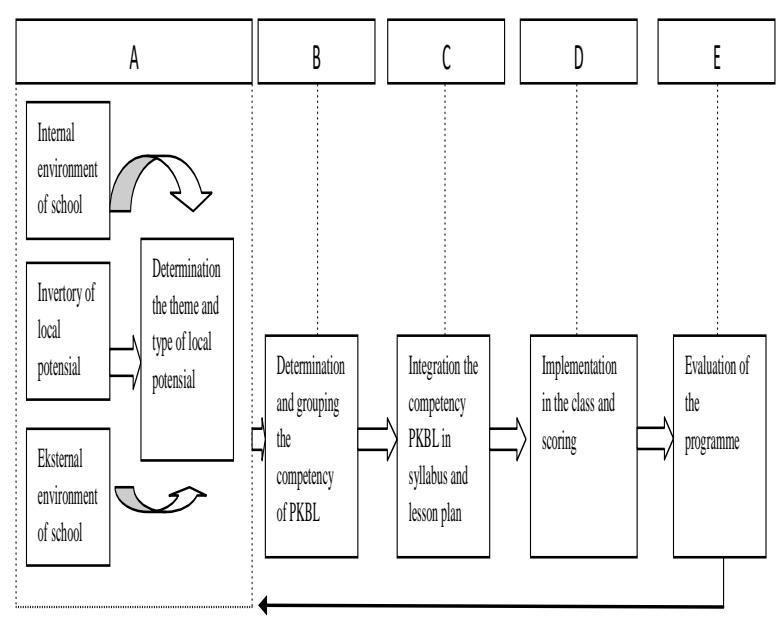


Fig. 1. The research phase based on Dit. PSMA-Ditjen Mandikdasmen

\section{Conservation Data Collection Techniques}

Data collection of SoE "keprok" orange production from 2005 to 2016 originating from BPS (Central Statistics Agency) of TTS [15-20]. Data were analyzed by the moving average (RRB) method every 2 years to determine the trend of SoE "keprok" production patterns [21]. RRB analysis using the Microsoft@ Office Excel 2003 (11.8404.8405) SP3 program. Furthermore, the tendency of SoE "keprok" production patterns is discussed based on the results of research on aspects of SoE "keprok" production conducted by other researchers.

\section{RESULTS AND DISCUSSION}

\section{A. Local potential of terrestrial ecosystem biome in the Tanggungharjo area}

Based on the stages of the research in Fig. 1., stage A obtained the results of observations and interviews with informants obtained a list of local potential terrestrial biome ecosystems in the area of Tanggungharjo presented in Table 1.

\section{TABLE 1. LIST OF LOCAL POTENTIAL OF LAND ECOSYSTEM BIOMES TANGGUNGHARJO AREA}

\begin{tabular}{|c|c|c|}
\hline No. & Ecosystems Type & Characteristics \\
\hline 1 & Karst & $\begin{array}{l}\text { Natural ecosystems, limited } \\
\text { and typical plant species } \\
\text { (teak and mahogany), typical } \\
\text { soil types dominated by } \\
\mathrm{CaCO}_{3} \text { content, underground } \\
\text { caves and rivers. }\end{array}$ \\
\hline 2 & Paddy fields & $\begin{array}{l}\text { Artificial ecosystems, the } \\
\text { main crop of rice (Oryza } \\
\text { sativa), are found with a } \\
\text { variety of plant pests, } \\
\text { wetlands, stagnant water. }\end{array}$ \\
\hline 3 & Soybean fields & $\begin{array}{l}\text { Artificial ecosystems, the } \\
\text { main crop of soybeans } \\
\text { (Glycine max), dry land, } \\
\text { sparse and non-stagnant } \\
\text { water. }\end{array}$ \\
\hline 4 & Corn fields & $\begin{array}{l}\text { Artificial ecosystems, the } \\
\text { main crop of corn (Zea } \\
\text { mays), dry land, sparse and } \\
\text { non-stagnant water. }\end{array}$ \\
\hline
\end{tabular}

The results of interviews with science junior high school teachers in Tanggungharjo sub-district stated that the teachers already knew what was meant by local potential. However, the teachers have not yet fully developed learning that leads to the utilization of local potential. Based on the results of the questionnaire, not all teachers identified any local potential in their area. Although the teacher has tried to apply some of the available local potentials, the teacher tends to choose to apply learning according to the steps contained in the teacher's book compared to developing his own learning.

In general, the local potentials applied by teachers include: the use of media other than land for planting special plants and water purification, the introduction of ecosystems around the school, the introduction of limestone mineral species, the introduction of the effects of teak logging, learning with the use of rice fields, the use of grasshoppers in teak forests as an alternative source of protein, and utilization of chicken manure and tofu waste. Some of the local potential described by the teacher relates to the characteristics of the Tanggungharjo terrestrial ecosystem which is dominated by terrestrial biome ecosystems in the form of karst ecosystems, teak forests, rice fields, soybean fields, and corn fields. Table 1 can be described in detail by ecosystem as follows:

\section{Karst ecosystem}

The Tanggungharjo region is included in the North Kendeng mountains group which is included in the karst area. Karst is a typical area formed by the karstification process, namely the dissolution of rocks dominated by carbonate content through the chemical reaction of water. The dissolution process begins with the dissolution of $\mathrm{CO}_{2}$ in water to form $\mathrm{H}_{2} \mathrm{CO}_{3} . \mathrm{H}_{2} \mathrm{CO}_{3}$ solution is unstable and breaks down into $\mathrm{H}^{+}$and $\mathrm{HCO}_{3}{ }^{2-}$. The $\mathrm{H}^{+}$ion further decomposes $\mathrm{CaCO}_{3}$ into $\mathrm{Ca}^{++}$and $\mathrm{HCO}_{3}{ }^{2-}$. The characteristics of karst areas are the existence of dry valleys or closed basins, difficult to find surface water reserves, and the number of caves in the ground [22]. Karst area soils have high permeability and porosity, so groundwater is very scarce and is deep in the soil. Water limitations in this area cause people to use water only for household needs such as washing, cooking, drinking, and bathing.

Based on the results of the analysis and in accordance with Table 1, in some basic competencies that can utilize the karst ecosystem at Tanggungharjo area as mention in Fig.2. as a source of learning can be described in the concept of classification, characteristics of living things, interactions of living things, pollution, excretion systems, and identification of food ingredients.

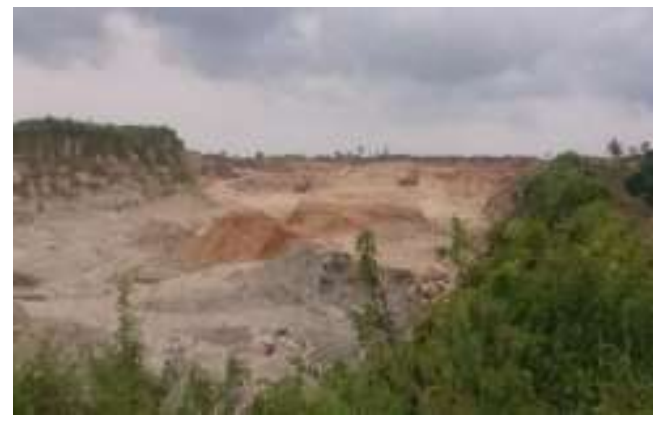

Fig. 2. Karst ecosystem at Tanggungharjo area

Damage to the karst ecosystem in mining in Fig. 3. that is practiced by the company due to the clearing of karst vegetation, results in erosion, reduced soil fertility, and karstic water source discharge that is starting to disappear. In addition, the karst area damage has the potential to damage the ecosystem of living things in the karst region including bats that live in karst caves are natural controllers of agricultural pests as well as pollinating various types of plants. Bats play an important counterweight in complex ecological processes through their interactions. Such as seed dispersal, pollination, and balancing insect populations [23]. 


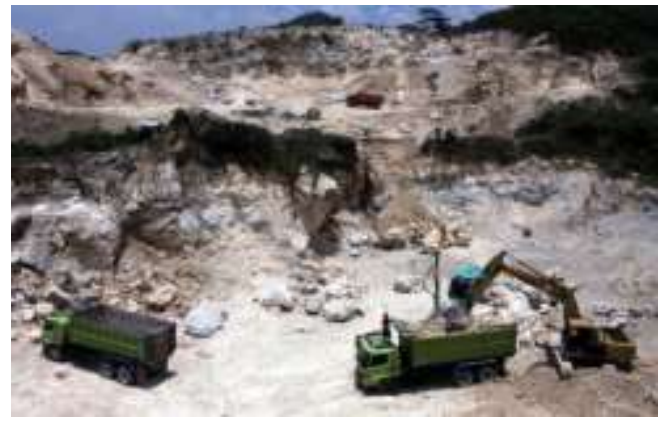

Fig. 3. Mining activities in Karst ecosystem at Tanggungharjo area

\section{Paddy Fields}

Paddy fields (rice fields) ecosystem is one of the dominant ecosystems in the Tanggungharjo area (Fig. 4.). This is evident from the annual rice production which reached 12,336 tons / ha, the second highest of production after corn [10]. The characteristics of this ecosystem are included in the artificial ecosystem, the main crop of rice (Oryza sativa), found in a variety of plant pests, wetlands, stagnant water.

Based on the results of the analysis and in accordance with Table 1, in some basic competencies that can utilize rice ecosystems as a source of learning can be described in the concept of classification, characteristics of living things, interactions of living things, and identification of food ingredients.

Rice plants can live well in areas that are hot and contain a lot of water vapor. Good rainfall averages $200 \mathrm{~mm}$ per month or more [24]. In addition to the biotic component, the paddy ecosystem is also composed by abiotic components including: soil, water, stone, air, light, temperature, humidity. Biotic and abiotic components form complex relationships, and influence each other to form ecological systems. In the paddy ecosystem consists of food chains that form food webs that we often see in energy flow material books as an example of food webs on rice ecosystems.

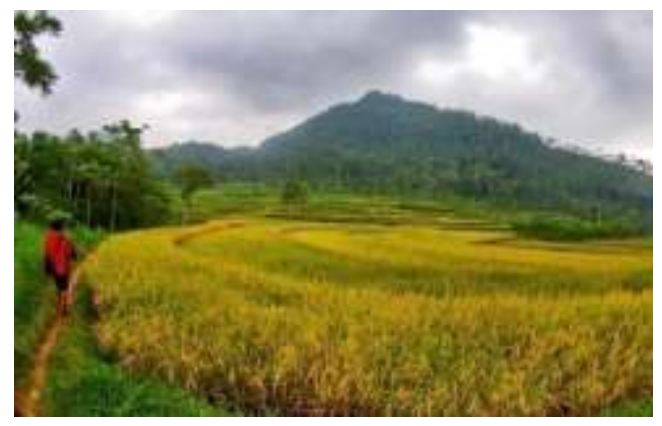

Fig. 4. Paddy fields ecosystem at Tanggungharjo area

\section{Corn field Ecosystem}

Corn field ecosystem is one of the ecosystems that dominates the Tanggungharjo area (Fig. 5.). This is evident from the annual corn production which reaches 45,888 tons / ha, higher than rice and soybean production [10].

Based on the results of the analysis and in accordance with Table 1, in some basic competencies can utilize the cornfield ecosystem as a source of learning can be described in class VII (KD 3.2, KD 3.7 and KD 3.8), class VIII (KD 3.5 and KD 3.10) and can utilize the ecosystem corn fields as a source of learning that can be elaborated on the concept of classification, characteristics of living things, interactions of living things, nutrition, applying the concept of inheritance in breeding, and pollution.

In addition to the biotic component, the cornfield ecosystem is composed by abiotic components including: soil, water, stone, air, light, temperature, humidity. Biotic and abiotic components form complex relationships, and influence each other to form ecological systems. In the cornfield ecosystem consists of food chains that form food webs and there is a flow of energy.

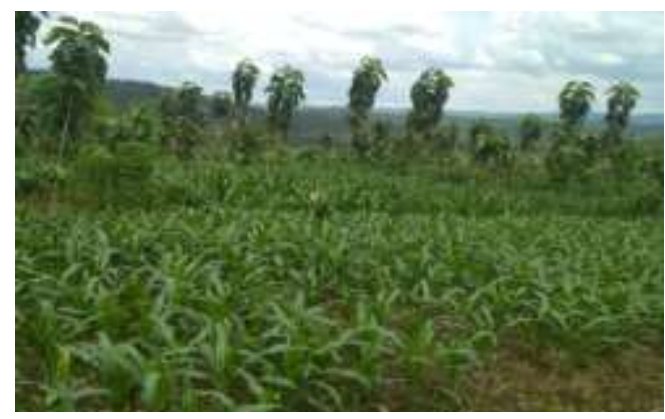

Fig. 5. Corn fields ecosystem at Tanggungharjo area

Pollution is an undesirable change from the environment which is largely a result of human activities [25]. Ecosystem changes due to human activities that destroy or waste the resources that are in vain in nature. In addition to food ingredients, biodegradable plastic packaging products have also been developed using corn starch extract. Corn can also be extracted as oil and industrial raw materials and raw materials for bioethanol production [26]. Reducing the use of plastic can certainly be a solution to the problem of environmental pollution.

\section{Soybean Ecosystem}

Soybean field ecosystem is one of the ecosystems found in the Tanggungharjo area (Fig. 6.). Production of soybeans in the responsibility ofharvest itself reaches 133 tons / ha, the lowest of rice and soybean production [10]. Based on the results of the analysis and in accordance with Table 1, in some basic competencies can utilize the soybean ecosystem as a source of learning can be described in the concept of classification, characteristics of living things, interactions of living things, nutrition, application of the concept of biotechnology.

Examples of the application of the concept of biotechnology are that people generally use soybeans as food for consumption at home, as well as making soybean processing as raw material for making processed food products for public consumption including tofu, tempeh, 
tauco, soy sauce. Therefore, microbes can be used to produce food or produce certain products.

Biotechnology is the principle of science and technology to process materials through biological agents in order to increase added value so that it is beneficial for human health. Biotechnology that is practiced in secondary schools includes traditional / conventional biotechnology instead of modern biotechnology which through very complicated processes using high technology. Examples of conventional biotechnology are tofu, tempeh, soy sauce, and tauco.

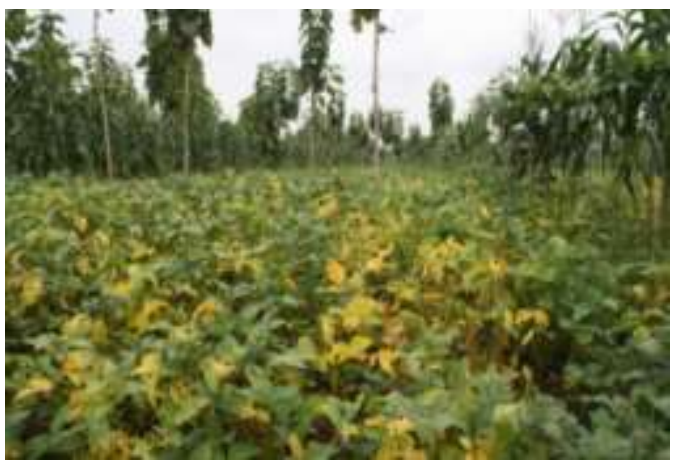

Fig. 6. Soybean fields ecosystem at Tanggungharjo area

The empowerment of environmental potential as a source of learning can support community-based character education (PPK) strengthening movements. Some characters that can be developed based on local potential in the Tanggungharjo area include the character of protecting the environment as a religious and nationalist sub-value, hard work and creative character as an independent character sub-value, cooperation character as a mutual cooperation character, and responsibility as a integrity character subvalue. The teacher is one of the key actors in developing learning activities that support the strengthening of character education.

The character of protecting the environment can be formed when students are aware of the existing pollution in the Tanggungharjo area, both in the form of soil, water and air pollution. The character of hard work is formed when students conduct activities of observation, identification, report making related to the karst ecosystem, etc. The character of cooperation is empowered when students conduct discussions related to the identification of living creatures found in the environment around karst areas, rice fields, community forests, and pajale farming areas. The character of responsibility is formed when students write a paper about maintaining the health of the excretion system to remind the public not to consume well water, creative character is formed when students think about solving pollution problems that occur in the environment around the karst area which is a mining area, trying to make products conventional biotechnology, for example making tempeh, soy sauce, tauco.

\section{B. Local Potential of "Keprok" oranges in SoE-TTS, NTT}

Orange species found in $\mathrm{SoE}$ are diverse. Orange found were 7 species in SoE-TTS, both cultivated and wildgrowing. Orange found can be seen in Table 2.

\begin{tabular}{|c|c|c|c|}
\hline No & Variety & Local Name & Spesies \\
\hline 1. & $\begin{array}{l}\text { Jeruk } \\
\text { keprok SoE }\end{array}$ & Lemon cina & Citrus reticulate \\
\hline 2. & Jeruk manis & lemon manis & Citrus sinensis \\
\hline 3. & Jeruk nipis & Lemon nipis & Citrus aurantifolia \\
\hline 4. & Jeruk purut & Lemon susu & Citrus hystrix \\
\hline 5 & $\begin{array}{l}\text { Jeruk } \\
\text { pamelo/Bali }\end{array}$ & Lemon pepermus & $\begin{array}{l}\text { Citrus grandis/ } \\
\text { maxima }\end{array}$ \\
\hline 6. & $\begin{array}{l}\text { Jeruk purut } \\
\text { (big size) }\end{array}$ & $\begin{array}{l}\text { Lemon asam (muke } \\
\text { naes) / jeruk purut }\end{array}$ & - \\
\hline 7. & $\begin{array}{l}\text { Jeruk nipis } \\
\text { besar }\end{array}$ & $\begin{array}{l}\text { Lemon asam (muke } \\
\text { masi) / jeruk nipis }\end{array}$ & - \\
\hline
\end{tabular}

Morphologically the diversity of oranges (Cirus) found in the TTS regency is seen in the shape of the stem, leaves, flower color, fruit shape, color and fruit flavor. Citrus diversity in SoE can be seen in fruit as seen in Fig. 7.

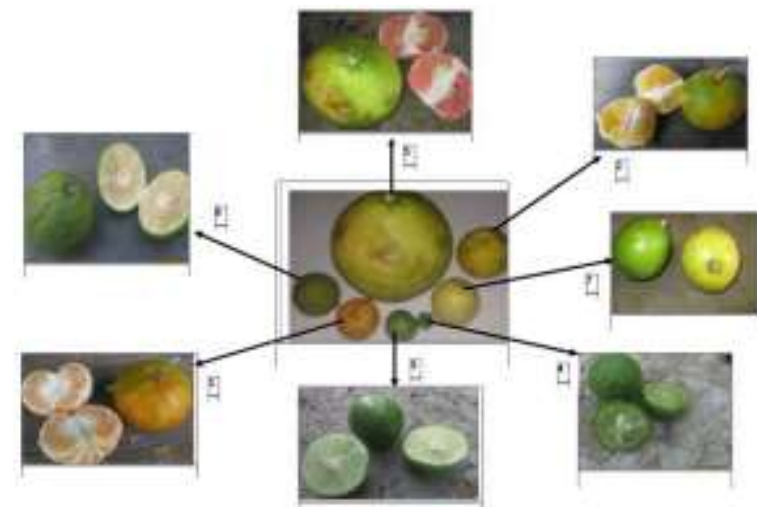

Fig. 7. Types of oranges in SoE - TTS Regency

The results of identification of orange fruit diversity in SoE, according to reference [27] have the shape, size, color and taste, are described in Table 3. The diversity of oranges in SoE.

TABLE 3. DESCRIPTION OF LOCAL ORANGE IN SoE-TTS REGENCY

\begin{tabular}{|l|l|}
\hline Name & \multicolumn{1}{|c|}{ Description } \\
\hline $\begin{array}{l}\text { 1.Jeruk Keprok SoE } \\
\text { Citrus reticulate) }\end{array}$ & $\begin{array}{l}\text { SoE Keprok are a superior } \\
\text { commodity preserved in SoE-TTS, } \\
\text { NTT. Round, short, at the base of } \\
\text { the fruit stem in the shape of a bun, } \\
\text { thin skin, and the seeds vary. } \\
\text { Variations are generally 3-6 cm } \\
\text { high, 4-7 cm in diameter when the } \\
\text { fruit is yellow (orange), shiny, } \\
\text { slippery and some are rough. Sweet } \\
\text { and slightly sour As food } \\
\text { ingredients (vit.C) economy, } \\
\text { fragrances, and research objects for } \\
\text { development. }\end{array}$ \\
\hline 2. Jeruk Manis \\
(Citrus sinensis) & $\begin{array}{l}\text { Sweet orange is one of the oranges } \\
\text { cultivated in So'E .. Round, round, } \\
\text { thick skin, fresh fruit flesh and } \\
\text { round seeds Vary generally in } \\
\text { Height } 4 \text { - 7cm, diameter 5-8cm } \\
\text { Still easy to green. dark, yellow }\end{array}$ \\
\hline
\end{tabular}




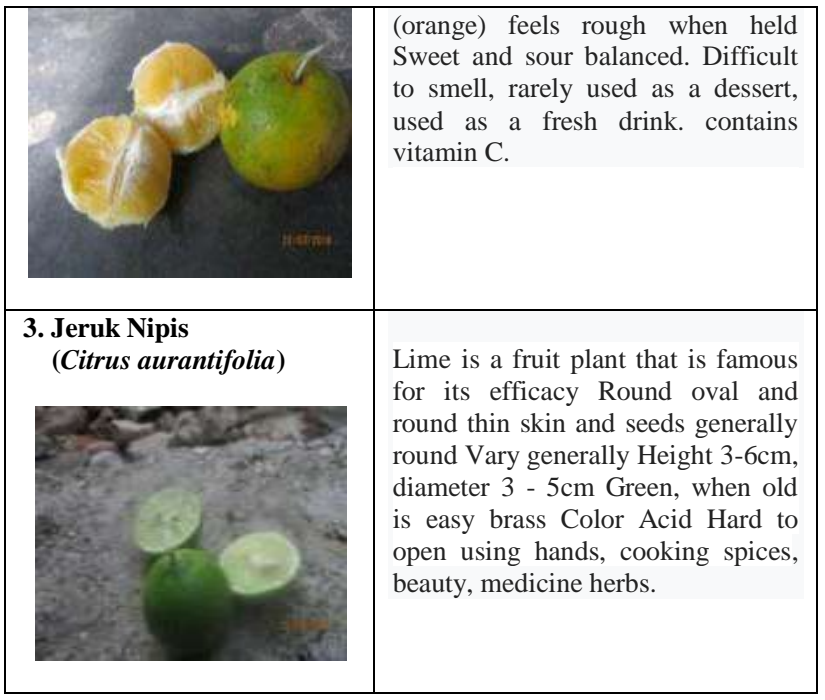

\begin{tabular}{|c|c|}
\hline $\begin{array}{l}\text { 4. Jeruk purut } \\
\text { (Citrus hystrix) }\end{array}$ & $\begin{array}{l}\text { Kaffir lime is an orange that has } \\
\text { an irregular shape. Round, thick } \\
\text { skin, irregular surface and rough } \\
\text { feel. Variations are generally } 2- \\
4 \mathrm{~cm} \text { high, and diameter is } 2-4 \\
\mathrm{~cm} \text { Green. At the time of the old } \\
\text { yellowish, acid, difficult to open } \\
\text { using hands, cooking spices, } \\
\text { beauty, herbal medicine but has } \\
\text { important benefits for humans. }\end{array}$ \\
\hline $\begin{array}{l}\text { 5. Jeruk Pamelo/Bali } \\
\text { (pepermus) / } \\
\text { (Citrus grandis / Citrus } \\
\text { maxima) }\end{array}$ & $\begin{array}{l}\text { Pepermus oranges are the biggest } \\
\text { oranges of the oranges in SoE } \\
\text { Kab. Rounded TTS Round, round } \\
\text { elps, Thick skin, sided seeds } \\
\text { Varied generally Height } 10-15 \\
\mathrm{~cm} \text {, diameter } 10-12 \mathrm{~cm} \text { Green, } \\
\text { easy yellow and dark yellow } \\
\text { Acid and slightly sweet Difficult } \\
\text { to open, generally made salad. }\end{array}$ \\
\hline $\begin{array}{l}\text { 6. Jeruk purut besar } \\
\text { (lemun asam) }\end{array}$ & $\begin{array}{l}\text { This sour lemon has the same } \\
\text { characteristics as kaffir lime, but } \\
\text { a larger size. Rounded round, } \\
\text { thick skin, irregular surface and } \\
\text { rough feeling Varies generally. } \\
\text { Height } 5-8 \mathrm{~cm} \text {, diameter } 5-8 \mathrm{~cm} \text {. } \\
\text { Green, when it is dark yellow } \\
\text { Acid is difficult to open using } \\
\text { hands, used as food and hair } \\
\text { shampoo. }\end{array}$ \\
\hline $\begin{array}{l}\text { 7. Jeruk nipis besar } \\
\text { (lemun asam) }\end{array}$ & $\begin{array}{l}\text { This sour lemon has the same } \\
\text { characteristics as a lime, but has a } \\
\text { larger size. Oval-shaped fruit, } \\
\text { thick skin, slippery surface } \\
\text { Varies generally. Height } 6-8 \mathrm{~cm} \text {, } \\
\text { diameter } 4-6 \mathrm{~cm} \text {. At the time of } \\
\text { the old yellow Acid is difficult to } \\
\text { open using hands, making food. }\end{array}$ \\
\hline
\end{tabular}

\section{Orange Conservation Efforts}

Citrus diversity found in TTS is a local commodity, both cultivated and wild-growing. These plants are beneficial to humans so they need to be preserved. However due to lack of knowledge about oranges and cultivation technology, existing citrus plants are not well managed, and reliable commodities such as SoE "keprok" are threatened with extinction. Various efforts to develop citrus plants have been carried out by the local government such as the preparation of seedlings, land, farmer group resources [28], but the effort has not been successful because the death of "keprok" continues to increase every year. Therefore it is necessary to have teaching materials about the various oranges that are there for students to understand so that they can maintain their sustainability. Efforts to preserve oranges can be done by planting and maintaining them.

\section{Planting}

Planting is an early stage in crop cultivation. In conservation efforts, planting is an attempt to re-establish or rejuvenate old plants. The steps taken as a conservation effort in planting are preparing seedlings, preparation of holes and how to plant. If planting technology is carried out correctly, plants will grow and develop properly [29].

\section{Maintain}

Caring is an effort to save plants (oranges) from threats, both from within the plant itself and from outside. Internal threats include nutrient deficiencies. While external threats include prolonged hot climate change, pest and disease attacks. The steps taken as a maintenance effort are watering, weeding, fertilizing, pruning, bending the branches, thinning fruits and controlling pests or diseases $[30,31]$.

\section{CONCLUSIONS}

1. Local advantages of terrestrial ecosystem biomes which were found in the Tanggungharjo area, namely karst ecosystems, paddy ecosystems, soybean field ecosystems and cornfield ecosystems. The application of the local excellence of terrestrial ecosystem biomes in the Tanggungharjo area has not yet been fully developed for learning that leads to the utilization of local excellence.

2. The existence of local excellence based education (PBKL), local advantages of terrestrial ecosystem biomes found in the Tanggungharjo area can be identified and integrated into subjects that are relevant to the basic competencies of Natural Sciences and Biology.

3. TTS Regency have 7 local citrus species both cultivated and wild-growing. Citrus in SoE is a local potential with promising prospects and potential for development in SoE, especially SoE Keprok. While planting and maintaining is an application of psychomotor competence, as an effort to conserve oranges.

\section{ACKNOWLEDGMENT}

Special thanks to the teachers of junior high school and the local citizens at Tanggungharjo, Grobogan Regency, Central Java province and the Principal of Kuanfatu State 
[22] Adji, T, Haryono, E.,2004, Geomorfologi dan Hidrologi Karst, https://www.researchgate.net/publication/290608050, diakses pada 11 Januari 2019.

Department of Education and Culture of NTT Province.

\section{REFERENCES}

[1] Ahmadi, I., Amri, S., dan Elisah, T. (2012). Mengembangkan Pendidikan Berbasis Keunggulan Lokal. Jakarta: Prestasi Pustaka.

[2] Wolf, S. J., \& Fraser, B. J.. (2008). Learning environment, attitudes and achievement among middle-school science students using inquiry-based laboratory activities. Research in Science Education, 38, 321-341.

[3] Mumpuni, K. E. (2013).'Potensi Pendidikan Keunggulan Lokal Berbasis Karakter dalam Pembelajaran Biologi'. JUPEMASI-PBIO Seminar Nasional X Pendidikan Biologi FKIP UNS. Diterima dari http://jurnal.fkip.uns.ac.id/index.php/prosbio/article/view/3137.

[4] Undang-undang Republik Indonesia No.20 tahun 2003 tentang Sistem Pendidikan Nasional. https://kelembagaan.ristekdikti.go.id > uploads > 2016/08

[5] Setyowati, Hetty. (2006). Keefektifan Penggunaan Pendekatan Kontekstual (Contextual Teaching Learning) Dalam Pembelajaran Biologi Sub Pokok Bahasan Tumbuhan Berbiji Di Kelas VII SMPN I Dawe Kudus Tahun Ajaran 2005/2006. Skripsi. Semarang: Universitas Negeri Semarang.

[6] Ibrohim. (2015). Pengembangan Pembelajaran IPA/Biologi Berbasis Discovery/Inquiry dan Potensi Lokal untuk Meningkatkan Keterampilan dan Sikap Ilmiah serta Menumbuhkan Jiwa Kewirausahaan. Dalam Prosiding Semnas Sains \& Entrepreneurship II Universitas PGRI . Semarang.

[7] Prihantini. (2014). Pengembangan Kurikulum Pendidikan Berbasis Keunggulan Lokal (Pbkl) [Thesis]. Bandung: Program Studi Pengembangan Kurikulum Sekolah Pascasarjana, Univ. Pendidikan Indonesia.

[8] Badan Perencanaan Pembangunan Daerah (BAPPEDA) Grobogan. (2012). Letak Geografis dan Sumber Daya Alam Kabupaten Grobogan. Diterima dari https://bappeda.grobogan.go.id/dokumen/data-statistik/35-letakgeografis-dan-sumber-daya-alam-kabupaten-grobogan.

[9] SLHD. (2012). Buku Laporan SLHD Kabupaten Grobogan 2012. Grobogan: Tim Cetak Grobogan.

[10] BPS. (2016). Badan Pusat Statistik Kabupaten Grobogan. https://grobogankab.bps.go.id/subject/53/tanamanpangan.html\#subjekViewTab3.

[11] Martosupono, M., Semangun, H., dan Sunbanu, B.Y., "Budidaya Jeruk Keprok SoE di Kabupaten Timor Tengah Selatan", Agric, vol. 19, no. 1 dan 2, pp. 76-90, 2007.

[12] Prawirohartono S. (2016). Konsep dan Penerapan Biologi SMA/MA Kelas X Kelompok Peminatan MIPA.Edisi 2016.PT. Bumi Aksara. Jakarta

[13] Astirin O. P.(2000). "Permasalahan Pengelolaan Keanekaragaman Hayati di Indonesia". Biodiversitas, Volume 1, nomor 1, hal 38 -39

[14] Sugiyono. (2016). metodologi penelitian kuantitatif, kualitatif, dan r\&d. bandung: cv alfabeta.

[15] BPS (Badan Pusat Statistik) Kabupaten Timor Tengah Selatan), Timor Tengah Selatan dalam Angka 2008. BPS Kabupaten Timor Tengah Selatan, 2008.

[16] BPS (Badan Pusat Statistik) Kabupaten Timor Tengah Selatan), Timor Tengah Selatan dalam Angka 2010. BPS Kabupaten Timor Tengah Selatan, 2010.

[17] BPS (Badan Pusat Statistik) Kabupaten Timor Tengah Selatan), Timor Tengah Selatan dalam Angka 2013. BPS Kabupaten Timor Tengah Selatan, 2013.

[18] BPS (Badan Pusat Statistik) Kabupaten Timor Tengah Selatan), Timor Tengah Selatan dalam Angka 2015. BPS Kabupaten Timor Tengah Selatan, 2015.

[19] BPS (Badan Pusat Statistik) Kabupaten Timor Tengah Selatan), Timor Tengah Selatan dalam Angka 2016. BPS Kabupaten Timor Tengah Selatan, 2016.

[20] BPS (Badan Pusat Statistik) Kabupaten Timor Tengah Selatan), Timor Tengah Selatan dalam Angka 2017. BPS Kabupaten Timor Tengah Selatan, 2017.

[21] Spigel M.R. and L.J. Stephens, Theory and Problem of Statistics. McGraw-Hill Companies Inc., 1998.

[23] Aguirre, L., Lens, L., \& Matthysen, E. (2003). Pattern of Roost use by bats in a neotropical savanna: imlications for conservation. $J$ Biological Conservation 111,435-443, http://journal.uinjkt.ac.id/index.php/kauniyah/article/view/2694/2066.

[24] Purwono, dan Purnamawati, H. (2008). Budidaya 8 Jenis Tanaman Pangan Unggul. Jakarta: Penebar Swadaya.

[25] Darmono, 2001, Lingkungan Hidup dan Pencemaran (Hubungannya dengan Toksikologi Senyawa Logam), Universitas Indonesia Press, Jakarta.

[26] Krisnamurthi, B. (2010). Manfaat Jagung dan Peran Produk Bioteknologi Serealia dalam Menghadapi Krisis Pangan, Pakan dan Energi di Indonesia, Prosiding Pekan Serealia Nasional 2010.

[27] Rezkianti,V., Maemunah, dan I. Lakani," Identifikasi Morfologi dan Anatomi Jeruk Lokal (citrus sp.) Di Desa Hangira dan Desa Baleura Kecamatan Lore Tengahkabupaten Poso", e-J. Agrotekbis 4 (4) : 412-418, 2016.

[28] Permasalahan Serta Strategi yang Dilakukan Pemerintah Daerah Kabupaten Timor Tengah Selatan dalam Pengembangan Jeruk Keprok SoE. http://balitjestro.Litang.Pertanian.go.id (oktober 2012).

[29] Bernadus. Y. Sunbanu, "Kendala Reproduksi Jeruk Keprok Soe di Kabupaten Timor Tengah Selatan, ditinjau dari aspek Biologi”, M.B. Tesis, UKSW 2005.

[30] Widyawati dan Nurbani, "Teknologi inovasi budidaya Jeruk Keprok Borneo Prima di Kalimantan Timur", Prosiding Seminar Nasional Masyarakat Biodiversitas Indonesia, vol. 3, nomor 1, hal. 127$131,2007$.

[31] Murdolelono B., Yusuf, dan C.Y. Bora, " Masalah dan Alternatif Pengendalian Penyakit Jeruk Keprok Soe di Nusa Tenggara Timur", .Jurnal Pengkajian dan Pengembangan Teknologi Pertanian Vol. 7, No.1,pp. 43-53, 2000. 